\title{
Increased muscle fatty acid oxidation in dairy cows with intensive body fat mobilization during early lactation
}

\author{
C. Schäff, ${ }^{*}$ S. Börner, ${ }^{*}$ S. Hacke, ${ }^{*}$ U. Kautzsch, ${ }^{*}$ H. Sauerwein,† S. K. Spachmann, ${ }^{*}$ M. Schweigel-Röntgen, ${ }^{*}$ \\ H. M. Hammon,* and B. Kuhla*1 \\ *Institute of Nutritional Physiology "Oskar Kellner," Leibniz Institute for Farm Animal Biology (FBN), Wilhelm-Stahl-Allee 2, 18196 Dummerstorf, \\ Germany \\ †Institute of Animal Science, Physiology \& Hygiene Unit, University of Bonn, 53115 Bonn, Germany
}

\begin{abstract}
The beginning of lactation requires huge metabolic adaptations to meet increased energy demands for milk production of dairy cows. One of the adaptations is the mobilization of body reserves mainly from adipose tissue as reflected by increased plasma nonesterified fatty acid (NEFA) concentrations. The capacity of the liver for complete oxidation of NEFA is limited, leading to an increased formation of ketone bodies, reesterification, and accumulation of triglycerides in the liver. As the skeletal muscle also may oxidize fatty acids, it may help to decrease the fatty acid load on the liver. To test this hypothesis, 19 German Holstein cows were weekly blood sampled from 7 wk before until 5 wk after parturition to analyze plasma NEFA concentrations. Liver biopsies were obtained at d 3,18, and 30 after parturition and, based on the mean liver fat content, cows were grouped to the 10 highest (HI) and 9 lowest (LO). In addition, muscle biopsies were obtained at $\mathrm{d}-17,3$, and 30 relative to parturition and used to quantify mRNA abundance of genes involved in fatty acid degradation. Plasma NEFA concentrations peaked after parturition and were 1.5-fold higher in HI than LO cows. Muscle carnitine palmitoyltransferase $1 \alpha$ and $\beta$ mRNA was upregulated in early lactation. The mRNA abundance of muscle peroxisome proliferator-activated receptor $\gamma$ $(P P A R G)$ increased in early lactation and was higher in $\mathrm{HI}$ than in LO cows, whereas the abundance of PPARA continuously decreased after parturition. The mRNA abundance of muscle PPARD, uncoupling protein 3, and the $\beta$-oxidative enzymes 3 -hydroxyacyl-coenzyme A ( $\mathrm{CoA})$ dehydrogenase, very long-chain acyl-CoA dehydrogenase, and 3-ketoacyl-CoA was greatest at $\mathrm{d}$ 3 after parturition, whereas the abundance of PPAR $\gamma$ coactivator $1 \alpha$ decreased after parturition. Our results indicate that around parturition, oxidation of fatty
\end{abstract}

Received March 14, 2013.

Accepted June 14, 2013.

${ }^{1}$ Corresponding author: b.kuhla@fbn-dummerstorf.de acids in skeletal muscle is highly activated, which may contribute to diminish the fatty acid load on the liver. The decline in muscle fatty acid oxidation within the first 4 wk of lactation accompanied with increased feed intake refer to greater supply of ruminally derived acetate, which as the preferred fuel of the muscle, saves long-chain fatty acids for milk fat production.

Key words: dairy cow, lactation, transition period, muscle fatty acid oxidation

\section{INTRODUCTION}

The transition from gestation to lactation is associated with huge metabolic changes in dairy cows. Although energy demand increases up to 4-fold (Bobe et al., 2004), mainly due to enormous milk secretion, feed intake seems not to meet the resulting energy requirements. Energy intake may even decrease by parturition and increases only slowly in the first week of lactation, resulting in a negative energy and nitrogen balance (Bell et al., 2000; Drackley et al., 2001; Doepel et al., 2002; Kuhla et al., 2011). This deficiency is compensated for by the mobilization of body reserves, which contributes to supply lipids, proteins, and amino acids to the mammary gland. The key nutrient for milk production, however, is glucose and, thus, only a small amount of glucose is available as an energy source for peripheral tissues. During this state of hypoglycemia, lipids gain importance as the main energy source while lipogenesis is simultaneously reduced (Bauman and Currie, 1980; Grummer, 1993). The switch in systemic fuel selection is under endocrine control enabling large metabolic flexibility of many peripheral organs to support milk synthesis (Bauman and Currie, 1980).

The skeletal muscle is a major protein reserve and thus source of amino acids and its degradation may already start in late gestation (van der Drift et al., 2012). The extent of protein degradation, not only in muscle but also in other tissues, is supposed to be mirrored by plasma concentrations of branched-chain amino acids (BCAA) or 3-methyl histidine (3-MH; Doepel et al., 
2002; Nicastro et al., 2012). Released amino acids are not only utilized for milk protein synthesis but are also required for hepatic gluconeogenesis (Bell et al., 2000).

Triglycerides from adipose tissue are mobilized starting during the last week of gestation, resulting in an increased release of NEFA, which are oxidized by the liver and other tissues as an energy source (Grummer, 1993). However, the hepatic capacity for NEFA utilization is limited, contributing to the development of fatty liver in early lactation. Thus, the oxidative capacity in other tissues such as skeletal muscle could diminish the metabolic load of FA on the liver, although muscle tissue itself is degraded.

One key regulator of the muscle's oxidative metabolism is the phosphorylation status of the AMP-activated protein kinase (AMPK). Its activated (phosphorylated) form causes the repression of ATP-consuming processes and stimulates FA oxidation (FAO), whereas it lowers FA synthesis (Kahn et al., 2005). The FAO in skeletal muscle is also promoted by the adipokine leptin, which is predominantly produced by adipose tissue (Fuentes et al., 2010). Next to AMPK and leptin, other key regulators of FAO are well known. Most prominent is the peroxisome proliferator-activated receptor (PPAR) family (including the $\alpha, \gamma$, and $\delta$ forms), with $P P A R D$ being the most abundant member in skeletal muscle, but also $P P A R G$ and its coactivator

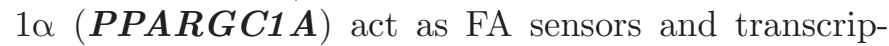
tion factors regulating muscle FAO (Evans et al., 2004; Muoio and Koves, 2007; Moreno et al., 2010). Longchain FA are transported into the mitochondria via the carnitine palmitoyltransferase 1 (CPT1) transporter system. In skeletal muscle, $C P T 1 B$ is the predominant isoform (Price et al., 2003). Very long-chain acyl-CoA dehydrogenase (ACA $\boldsymbol{D} \boldsymbol{V} \boldsymbol{L}$; Zammitt, 1984) and, apart from its function in thermogenesis, uncoupling protein 3 (UCP3; Schrauwen and Hesselink, 2004) are also regulators for FA transport into and out of the mitochondria. Once in the mitochondria, FA are $\beta$-oxidized in an NADH-dependent process mediated by 4 major enzymes, including $A C A D V L$. Elevated mRNA expression of these muscle $\beta$-oxidative enzymes has been described in early lactating sows (Ringseis et al., 2011), pointing to an increased muscle FAO, which should help to reduce the FA load on the liver. The extent to which the skeletal muscle of dairy cows participates in the degradation of FA during early lactation is not known. Our hypothesis was that skeletal muscle FA degradation adapts to the extent of fat mobilization during early lactation. To test this idea, we examined the expression of selected candidate genes at the mRNA level and their putative interaction with plasma metabolites in dairy cows with a different intensity of body tissue mobilization during early lactation.

\section{MATERIALS AND METHODS}

\section{Animals, Feeding, and Zootechnical Data}

All treatments were in accordance with the guidelines for the use of animals as experimental subjects of the State Government in Mecklenburg-Western Pomerania (Registration No. LALLF M-V/TSD/7221.32.1-021/09). The experimental design was described previously (Schäff et al., 2012). Briefly, 20 German Holstein cows in their second to fourth lactation were liver biopsied on $\mathrm{d}-34,-17,3,18$, and 30 relative to parturition and grouped according to their mean liver fat content after parturition as a measure of body fat mobilization to the lowest [LO; liver fat content $<24 \%$ $(20.0 \pm 2.0 \%)$ total fat/DM; $\mathrm{n}=9$ ] and highest [HI; liver fat content $>24.4 \%(30.2 \pm 1.8 \%)$ total fat/DM; $\mathrm{n}$ $=10]$ mobilizing cows. Due to its severe sickness during the trial, 1 LO cow was excluded from sampling.

Cows were housed in a tie-stall and fed twice daily (0600 and $1500 \mathrm{~h}$ ) 1 of 3 different TMR according to the recommendations of the German Society of Nutrition Physiology (GfE, 2001). The TMR compositions are shown in Table 1. Samples of the individual silages used were taken weekly to determine the content of DM. Feed intake was recorded daily and BW was measured weekly to calculate DMI and energy balance (EB). Energy balance (expressed in $\mathrm{MJ} / \mathrm{cow} \times \mathrm{d}$ ) was calculated for the dry period as $\mathrm{EB}=\mathrm{NE}_{\mathrm{L}}$ intake $-(0.293 \times$ $\mathrm{kg}$ of $\mathrm{BW}^{0.75}+0.044 \times \mathrm{e}^{0.0165 \times \text { days since conception }}$ ) ( GfE, 2001). After parturition, cows were milked twice daily (0330 and $1500 \mathrm{~h}$ ). Milk samples were taken weekly and analyzed for crude fat, CP, and lactose by an infrared spectrophotometric method (MilkoScan; Foss GmbH, Rellingen, Germany) to calculate ECM as follows: $\mathrm{ECM}=[(0.038 \times \mathrm{g}$ of crude fat $+0.024 \times \mathrm{g}$ of $\mathrm{CP}+$ $0.017 \times \mathrm{g}$ of lactose) $\times \mathrm{kg}$ of milk $\div 3.14$ (Reist et al., $2002)$. For the lactation period, EB was calculated as $\mathrm{EB}=\mathrm{NE}_{\mathrm{L}}$ intake $-\left(0.293 \times \mathrm{BW}^{0.75}+3.14 \times \mathrm{ECM}\right)$ (Hammon et al., 2009). Back fat thickness (BFT) and thickness of the musculus longissimus dorsi (MLDT) were measured weekly via ultrasound (SonoSite 180 Plus; SonoSite Inc., Bothell, WA).

\section{Blood Sampling and Analyses}

Weekly blood samples were taken from the jugular vein in EDTA-containing tubes. During the 2 wk before and 2 wk after parturition, 2 blood samples per week were obtained. Samples were immediately placed on ice and centrifuged within $30 \mathrm{~min}$ (at 1,565 $\times \mathrm{g}$ for $20 \mathrm{~min}$ at $4^{\circ} \mathrm{C}$ ). The obtained plasma was stored at $-80^{\circ} \mathrm{C}$ until photometrical analyses for NEFA, BHBA, glucose, and lactate as described previously (Schäff et al., 2012). 
Table 1. Components and chemical composition of diets fed as TMR during the far-off dry period, close-up dry period, and early lactation

\begin{tabular}{|c|c|c|c|}
\hline \multirow[b]{2}{*}{ Component } & \multicolumn{3}{|c|}{ Diet } \\
\hline & $\begin{array}{c}\text { Far-off } \\
\text { dry period }^{1}\end{array}$ & $\begin{array}{l}\text { Close-up } \\
\text { dry period }\end{array}$ & $\begin{array}{c}\text { Early } \\
\text { lactation }\end{array}$ \\
\hline \multicolumn{4}{|l|}{ Ingredient $(\mathrm{g} / \mathrm{kg}$ of $\mathrm{DM})$} \\
\hline Grass silage & 744 & 302 & 202 \\
\hline Corn silage & 37 & 399 & 350 \\
\hline Barley straw & 115 & 54 & 16 \\
\hline Hav & 92 & 39 & 26 \\
\hline Concentrate & $1.4^{2}$ & $124^{2}$ & $296^{3}$ \\
\hline Molassed sugar beet pulp ${ }^{4}$ & 4.1 & 5.5 & 62 \\
\hline Extracted rapeseed meal & & 45 & 32 \\
\hline Mineral feed & $7.7^{5}$ & $1.8^{5}$ & $6.7^{6}$ \\
\hline Nonlactating mineral feed with anionic salts ${ }^{7}$ & & 12 & \\
\hline Cattle salt ${ }^{8}$ & & 1 & 0.7 \\
\hline Propylene glycol $^{9}$ & & 16 & 8.8 \\
\hline \multicolumn{4}{|l|}{ Chemical analysis } \\
\hline Utilizable $\mathrm{CP}^{10}(\mathrm{~g} / \mathrm{kg}$ of $\mathrm{DM})$ & 126 & 137 & 163 \\
\hline Crude fat $(\mathrm{g} / \mathrm{kg}$ of $\mathrm{DM})$ & 40 & 34 & 30 \\
\hline $\mathrm{NE}_{\mathrm{L}}^{10}(\mathrm{MJ} / \mathrm{kg}$ of DM) & 5.8 & 6.5 & 7.1 \\
\hline $\mathrm{NDF}(\mathrm{g} / \mathrm{kg}$ of $\mathrm{DM})$ & 354 & 324 & 296 \\
\hline $\mathrm{ADF}(\mathrm{g} / \mathrm{kg}$ of $\mathrm{DM})$ & 202 & 140 & 135 \\
\hline
\end{tabular}

${ }^{1}$ Far-off dry period: wk 7 to 4 before parturition, close-up dry period: wk 3 before until parturition.

${ }^{2}$ Universal 18/3 (Vollkraft): 20 to $40 \%$ cereals (triticale, rye, wheat, and barley), $25 \%$ rapeseed expeller, lower contents of malt germs, wheat gluten, wheat bran, peeled oat bran, beet pulp chips, molasses and glycerin, minerals, vitamins, $6.7 \mathrm{MJ}$ of $\mathrm{NE}_{\mathrm{L}} / \mathrm{kg}$ of $\mathrm{DM}$, and $160 \mathrm{~g}$ of utilizable protein $/ \mathrm{kg}$ of DM.

${ }^{3}$ MF 2000 (Vollkraft, Güstrow, Germany): 33\% extracted soy meal, 20\% corn, 17\% wheat gluten, 13\% wheat, $8 \%$ extracted rapeseed meal, $5 \%$ sugar beet pulp, $2 \%$ sodium hydrogen carbonate, $1.3 \%$ calcium carbonate, $0.2 \%$ sodium chloride, $8.0 \mathrm{MJ}$ of $\mathrm{NE}_{\mathrm{L}} / \mathrm{kg}$ of $\mathrm{DM}$, and $204 \mathrm{~g}$ of utilizable protein $/ \mathrm{kg}$ of DM.

${ }^{4}$ Trockenschnitzel (ATR Landhandel Arp, Thordsen, Rautenberg, Sollerupmühle, Germany): minerals, 7.3 MJ of $\mathrm{NE}_{\mathrm{L}} / \mathrm{kg}$ of $\mathrm{DM}$, and $153 \mathrm{~g}$ of utilizable protein $/ \mathrm{kg}$ of $\mathrm{DM}$.

${ }^{5}$ Rinderstolz 9235 (Salvana Tiernahrung GmbH, Sparrieshoop, Germany): $75 \%$ crude ash, $4.5 \%$ calcium, $6 \%$ phosphorus, $10 \%$ sodium, $12 \%$ magnesium, and vitamins.

${ }^{6}$ Rinderstolz 9522 (Salvana Tiernahrung GmbH): 92\% crude ash, 20\% calcium, 5\% phosphorus, 6\% magnesium, $8 \%$ sodium, and vitamins.

${ }^{7}$ Anionen-Mix 1141(Salvana Tiernahrung GmbH): 14\% calcium, $12.5 \%$ sulfur, $12 \%$ chlorine, $10 \%$ magnesium, $2 \%$ phosphorus, and vitamins.

${ }^{8}$ esco SOLSEL Mineralleckstein mit Kupfer (esco GmbH \& Co. KG, Hannover, Germany): 37\% sodium, $1.6 \%$ calcium, 0.6\% magnesium, and copper.

${ }^{9}$ Propylenglycol USP (Dr. Pieper Technologie und Produktentwicklung GmbH, Wuthenow, Germany).

${ }^{10}$ German Society of Nutrition Physiology (2001).

Plasma leptin was determined by an enzyme immunoassay according to Sauerwein et al. (2004). Around parturition, weekly means were calculated from the 2 samples obtained. Plasma amino acid concentrations were measured in samples obtained in wk $-4,-3,-1$, $1,2,3$, and 5 relative to parturition via HPLC (Schäff et al., 2012).

\section{Muscle Tissue Samples}

Biopsies of the semitendinosus muscle were taken before morning feeding at $\mathrm{d}-17,3$, and 30 relative to parturition, alternating on the left and the right side (Kuhla et al., 2011). To this end, the skin was shaved, disinfected (Braunoderm; B. Braun Melsungen AG, Melsungen, Germany), and a sample was taken with a custom-made biopsy instrument as described earlier (Kuhla et al., 2011). Muscle tissue was liberated from skin and subcutaneous fat, immediately snap frozen, and stored at $-80^{\circ} \mathrm{C}$.

\section{Muscle Fat, Protein, Glycogen, and Glucose Content}

Frozen muscle tissue was ground with a mortar and pestle under liquid $\mathrm{N}_{2}$. Muscle tissue $(50 \mathrm{mg}$ ) was dried in a muffle-type furnace at $105^{\circ} \mathrm{C}$ for $3 \mathrm{~h}$ to determine the DM content. Dried samples were analyzed for nitrogen and carbon content using a $\mathrm{C} / \mathrm{H} / \mathrm{N} / \mathrm{S}$ TruSpec CHNS Microanalyzer (Leco Instrumente $\mathrm{GmbH}$, Mönchengladbach, Germany). For the analysis of muscle glycogen, wet tissue $(25 \mathrm{mg})$ was applied to an enzyme-based starch kit (no. 10207748035; Boehringer 
Mannheim GmbH, Mannheim, Germany) and fat and protein content were then calculated according to the methods described previously (Kuhla et al., 2004).

\section{mRNA Preparation and Real-Time Quantitative Reverse-Transcription PCR}

Powdered muscle tissue $(50 \mathrm{mg})$ was homogenized with a FastPrep 120 centrifuge (Thermo Electron Corp., Saint-Herblain Cedex, France). Total RNA was extracted with TRIzol Reagent (Invitrogen Corp., Carlsbad, CA). The integrity and quality of total RNA was confirmed upon gel electrophoresis on agarose gel stained with ethidium bromide (Carl Roth $\mathrm{GmbH} \&$ Co. KG, Karlsruhe, Germany) and by the measurement of the optical density 260:280 ratio (i.e., the ratio of optical density at $260 \mathrm{~nm}$ to the optical density at 280 $\mathrm{nm}$ ). The absorption ratio was between 1.8 and 2.0 for all samples. Concentrations were detected spectrophotometrically on a NanoPhotometer (Implen GmbH, Munich, Germany). For cDNA synthesis, $1 \mu \mathrm{g}$ of RNA was reverse-transcribed with $200 \mathrm{U}$ of M-MLV Reverse Transcriptase, RNase H Minus, Point Mutant (Promega Corp., Madison, WI) and $100 \mathrm{pmol}$ of random primers (Invitrogen Corp.). The cDNA was purified using a High Pure PCR Product Purification Kit (Roche Diagnostics, Laval, QC, Canada) and stored at $-80^{\circ} \mathrm{C}$. Primer pairs were designed with Primer3 software version 0.4.0 (http://bioinfo.ut.ee/primer3-0.4.0/primer3//), unless otherwise mentioned in Supplemental Table S1 (available online at http://www.journalofdairyscience.org/). Real-time quantitative reverse-transcription (qRT)PCR was performed on a LightCycler 2.0 instrument with FastStart DNA Master ${ }^{\text {PLUS }}$ SYBR Green I Master Mix (Roche Diagnostics GmbH, Mannheim, Germany) with $2 \mu \mathrm{L}$ of cDNA. Each cDNA sample was analyzed in duplicate. To verify specific PCR products, a melting curve analysis program was performed after the last amplification cycle. Furthermore, product purity and size were confirmed by agarose gel electrophoresis and by sequencing (MegaBACE 1000; GE Healthcare, Freiburg, Germany). Result analysis was performed with LightCycler analysis software 4.05. Data were quantified according to the $2^{-\Delta \Delta \mathrm{CT}}$ method (where CT is the cycle threshold; Livak and Schmittgen, 2001), using splicing factor 3 subunit 1 (SF3A1), which was recommended earlier as the reference gene for normalization (Pérez et al., 2008) and found to be nonregulated in our samples.

\section{Phosphorylated AMPK ELISA}

Powdered muscle tissue $(20 \mathrm{mg})$ was extracted in $300 \mu \mathrm{L}$ of lysis buffer containing $1 \mathrm{~m} M$ EDTA, $0.5 \%$
Triton-X-100, $5 \mathrm{~m} M$ sodium fluoride, $6 \mathrm{M}$ urea, $10 \mu \mathrm{g} /$ $\mathrm{mL}$ leupeptin, $10 \mu \mathrm{g} / \mathrm{mL}$ pepstatin, $100 \mu M$ phenylmethanesulfonyl fluoride, $3 \mu \mathrm{g} / \mathrm{mL}$ aprotinin, $2.5 \mathrm{mM}$ sodium pyrophosphate, and $1 \mathrm{~m} M$ activated sodium orthovanadate dissolved in PBS. Extracts were diluted 6-fold in buffer containing $1 \mathrm{~m} M$ EDTA, $0.5 \%$ Triton$\mathrm{X}-100$, and $5 \mathrm{mM}$ sodium fluoride dissolved in PBS. The protein content was determined according to the Bradford method, with BSA as standard. Diluted extracts $(100 \mu \mathrm{L})$ were applied to the ELISA DuoSet IC (DYC3528-2; R\&D Systems Inc., Minneapolis, MN) to determine the concentration of phosho-AMPKo1 (Thr174).

\section{Statistical Analysis}

All data were evaluated by repeated measures ANOVA using PROC MIXED of SAS/STAT software in the SAS System for Windows, release 9.2 (SAS Institute, 2009). Fixed effects for all analyses were group, time, and group $\times$ time; for $q R T-P C R$, technical replicate was additionally added as fixed effect. For blood metabolites and zootechnical data, analyses were performed separately for the prepartal period (wk -7 to -1 relative to parturition), the postpartal period (wk 1 to 5 relative to parturition), the transition period ( $\mathrm{wk}-3$ to 3 relative to parturition), and over the entire time period (wk -7 to 5 relative to parturition). Least squares means were calculated and presented with their standard errors for the entire time period, unless otherwise indicated. Differences were declared as significant at $P$ $<0.05$ and as trends at $0.05 \geq P<0.10$. The mRNA abundance and plasma NEFA concentration differences between $\mathrm{d} 3$ and $\mathrm{d}-17$ as well as between $\mathrm{d} 30$ and d 3 were calculated for each cow separately, yielding $\Delta$-values. These $\Delta$-values were tested for Pearson correlations with PROC CORR of SAS (SAS Institute, 2009) and correlations with $P \leq 0.05$ were considered as significant.

\section{RESULTS}

\section{Zootechnical and Milk Variables}

The DMI increased with time $(P<0.001$; Figure 1), but did not differ between $\mathrm{HI}$ and LO cows. Body weight, BFT, and MLDT were higher in HI cows $(P=$ $0.003, P<0.001$, and $P=0.02$, respectively; Figure 1 ) and in both groups higher before than after parturition $(P<0.001)$. Energy balance was not different between groups but reached a minimum, whereas liver fat content peaked after parturition $(P<0.001$; Figure $1)$. Milk yield $(P=0.78)$ and ECM yield $(P=0.39)$ did not differ between groups. The HI cows had higher 
milk fat content $(P<0.05)$, whereas LO cows showed higher milk urea content $(P=0.01)$ and tended to have more milk lactose $(P=0.09)$. Milk protein content did not differ between $\mathrm{HI}$ and LO cows $(P=0.8$; Table 2$)$.

\section{Plasma Metabolites Around Parturition}

Before parturition, plasma NEFA concentrations did not differ between groups but thereafter were higher in HI compared with LO cows (Table 3). Plasma 3-MH concentrations peaked around parturition $(P<0.001$; Table 3) without differences between groups. Plasma leptin concentrations tended $(P=0.10)$ to be greater for the HI cows, both prepartum and for the entire study. Plasma BHBA, glucose, and lactate concentrations were not different between groups. However, BHBA concentrations significantly increased during the transition period and thereafter $(P<0.001)$, whereas glucose $(P<0.001)$, lactate $(P=0.01)$, and leptin $(P<0.001)$ concentrations decreased after parturition, with the latter showing a group $\times$ time interaction in the transition period ( $P=0.02$; Table 3$)$. Plasma BCAA tended to be higher in LO cows, before and after parturition $(P$ $=0.08$; Table 3 ).

\section{Muscle Tissue and qRT-PCR}

Muscle fat content was higher in HI cows $(P=0.04)$, whereas muscle protein, glycogen, and glucose content were unaltered between groups $(P=0.51,0.46$, and 0.13 , respectively; Table 4).

The PPARA mRNA abundance decreased over time $(P<0.001 ;$ Figure 2$)$, with no differences between groups, whereas PPARG abundance increased from gestation to early lactation $(P=0.02)$ in HI but not in LO cows $(P=0.04$; Figure 2$)$. Abundance of PPARD was highest around parturition $(P<0.001)$ in both groups and tended to be higher in LO cows after parturition $(P<0.07)$, showing a group $\times$ time interaction $(P=0.03$; Figure 2$)$. Abundance of PPARGC1A markedly decreased after parturition $(P<0.001$; Figure 2$)$ in both groups. The isoforms $C P T 1 A$ and $C P T 1 B$ were upregulated in early lactation $(P<0.001$; Figure 2$)$ and a group $\times$ time interaction $(P=0.05)$ was observed for CPT1B. The mitochondria-specific FA-degrading enzymes 3-hydroxyacyl-CoA dehydrogenase $(\boldsymbol{H} \boldsymbol{A} \boldsymbol{D H})$, $A C A D V L$, and 3-ketoacyl-CoA thiolase (ACA $\boldsymbol{A} \boldsymbol{2})$ showed no differences between groups but were highest in abundance around parturition $(P<0.05$; Figure 2$)$. Also, UCP3 abundance increased from pregnancy to early lactation $(P<0.001)$ in both groups, but only in $\mathrm{HI}$ cows $U C P 3$ abundance remained elevated during the entire early lactation period (group $\times$ time interaction: $P=0.02$; Figure 2). Phosphorylation of AMPK in muscle tissue did not differ between groups $(P=0.6)$ or with time $(P=0.3$; Figure 2$)$.

\section{Correlations Between mRNA Abundances and Plasma NEFA Concentrations}

From $\mathrm{d}-17$ to 3 , changes in $C P T 1 B$ mRNA abundance correlated positively with $A C A D V L$ and $A C A A 2$, the latter additionally correlated positively with $H A D H$ but negatively with changes in PPARG abundance. Changes in UCP3 mRNA abundance correlated positively with PPARGC1A and NEFA (Figure 3). From d 3 to 30 , significant correlations were found between changes in $C P T 1 B$ and $A C A A 2$ and between changes in ACAA2 and PPARG abundance. Furthermore, alterations in $C P T 1 B$ abundance correlated positively with changes in $H A D H$ abundance. Expression changes for CPT1A were, in contrast to the prepartal period, positively correlated with changes in PPARA, PPARD, PPARGC1A, UCP3, and NEFA abundance. The latter additionally correlated positively with PPARD, PPARGC1A, and UCP3 abundance.

\section{DISCUSSION}

Dairy cows investigated in the present study originated from one commercial farm before being brought to our institute where they were kept under identical environmental conditions. According to the LFC postpartum, we retrospectively grouped cows into $\mathrm{HI}$ and LO groups, whereas during the dry-off period, LFC did not differ between groups. However, HI cows had the greater BFT, muscle fat content, MLDT, and BW already before parturition, suggesting their greater potential to mobilize more body fat and body protein than LO cows. The extent of postpartum mobilization of subcutaneous fat, however, does not depend on the level of prepartum BFT, BCS, or BW (Janovick and Drackley, 2010; Weber et al., 2013). In the study by Kessel et al. (2008), it was shown that cows with an equal BFT and equal BW before calving may lose BW after calving to a different extent, likely because mobilization from other depots such as from visceral or inter- and intramuscular fat depots contributes to BW reduction. As the latter fat depots are hard to quantify, classifying cows with different extent of body fat mobilization based on LFC postpartum seems to be more appropriate, at least because LFC was positively related to $\mathrm{BW}$ changes but not to $\mathrm{BFT}$ changes after calving (Weber et al., 2013).

The mobilization of skeletal muscle protein reserves in dairy cows starts already in late gestation and reaches a maximum between wk 2 before and wk 4 after parturition (van der Drift et al., 2012). In accordance with 

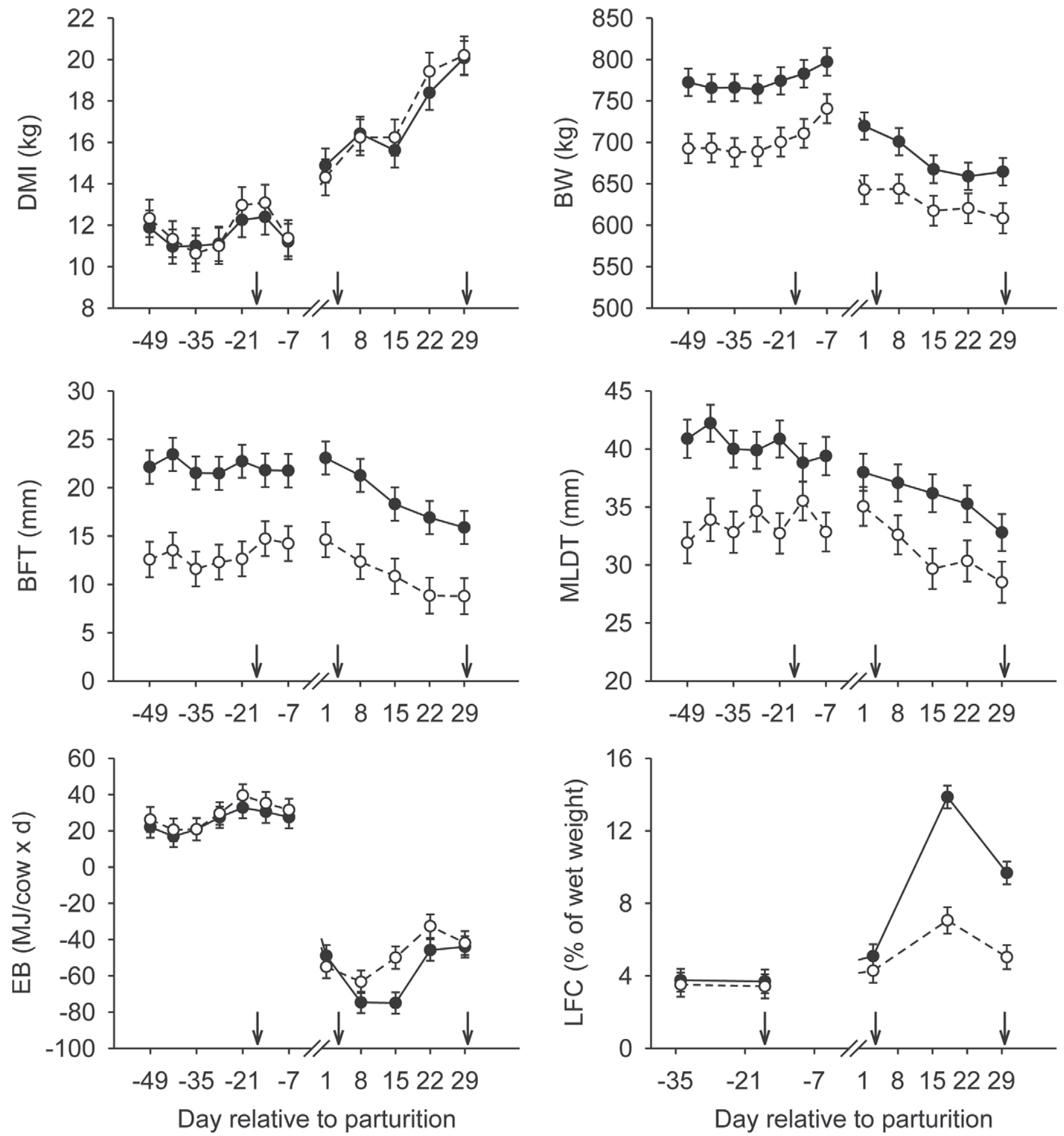

Figure 1. Dry matter intake, BW, back fat thickness (BFT), muscle (musculus longissimus dorsi) thickness (MLDT), energy balance (EB), and liver fat content (LFC) in cows with a low $(O)$ or high $(\bullet)$ extent of body fat mobilization. Times of muscle biopsies taken are indicated with arrows. All parameters changed with time $(P<0.001)$ and differed between the highest-body-fat-mobilizing $(\mathrm{HI})$ and lowest-body-fat-mobilizing (LO) cows for BFT, MLDT, EB, LFC $(P<0.001)$, and BW $(P=0.003)$ except DMI, which was equal in both groups $(P=0.71)$. 
Table 2. Milk yield and milk constituents of cows developing a low (LO) or high (HI) liver fat content (LFC) postpartum ${ }^{1}$

\begin{tabular}{|c|c|c|c|c|c|c|c|}
\hline Variable, wk 2 to 5 & \multicolumn{4}{|c|}{ LFC } & \multicolumn{3}{|c|}{ ANOVA $P$-value } \\
\hline Milk yield (kg) & 41.72 & 1.70 & 41.15 & 1.59 & 0.78 & $<0.001$ & 0.18 \\
\hline Milk protein (\%) & 3.13 & 0.08 & 3.11 & 0.08 & 0.84 & $<0.001$ & 0.61 \\
\hline Milk lactose (\%) & 4.81 & 0.05 & 4.72 & 0.05 & 0.087 & 0.24 & 0.37 \\
\hline Milk urea $(\mathrm{mg} / \mathrm{L})$ & 219.09 & 16.35 & 174.11 & 15.27 & 0.012 & 0.23 & 0.85 \\
\hline
\end{tabular}

${ }^{1}$ Data are presented as LSM with their SE.

these earlier findings, we found a continuously decreasing MLDT, particularly for HI cows from wk 4 before until wk 4 after parturition. Despite the significantly greater MLDT in HI compared with LO cows, plasma $3-\mathrm{MH}$ concentration, which has been proposed as a maker for muscle breakdown (Blum et al., 1985) did not differ between groups. Our finding is in contrast to earlier studies reporting higher 3-MH plasma concentrations in cows with a higher MLDT in the periparturient period (Doepel et al., 2002; van der Drift et al., 2012). Another indicator suggested for muscle degradation or anabolism, respectively, may be BCAA (Nicastro et al., 2012). As high plasma BCAA concentrations go along with less protein breakdown (Zanchi et al., 2008) and LO cows tended to have higher BCAA concentrations, LO cows seemed to degrade less muscle protein during the periparturient period compared with HI cows. This difference is reflected by a different MLDT decrease in $\mathrm{HI}$ and LO cows in early lactation.

Subcutaneous BFT decreased after parturition. The extent was equal in cows possessing a different BFT before parturition, which agrees with an earlier study

Table 3. Plasma metabolites of cows classified for either low (LO) or high (HI) liver fat content (LFC) postpartum calculated separately for the prepartal period ( $\mathrm{wk}-7$ to -1 ), the transition period ( $\mathrm{wk}-3$ to +3 ), the postpartal period (wk +1 to +5 ), and over the entire study (wk -7 to +5$)^{1}$

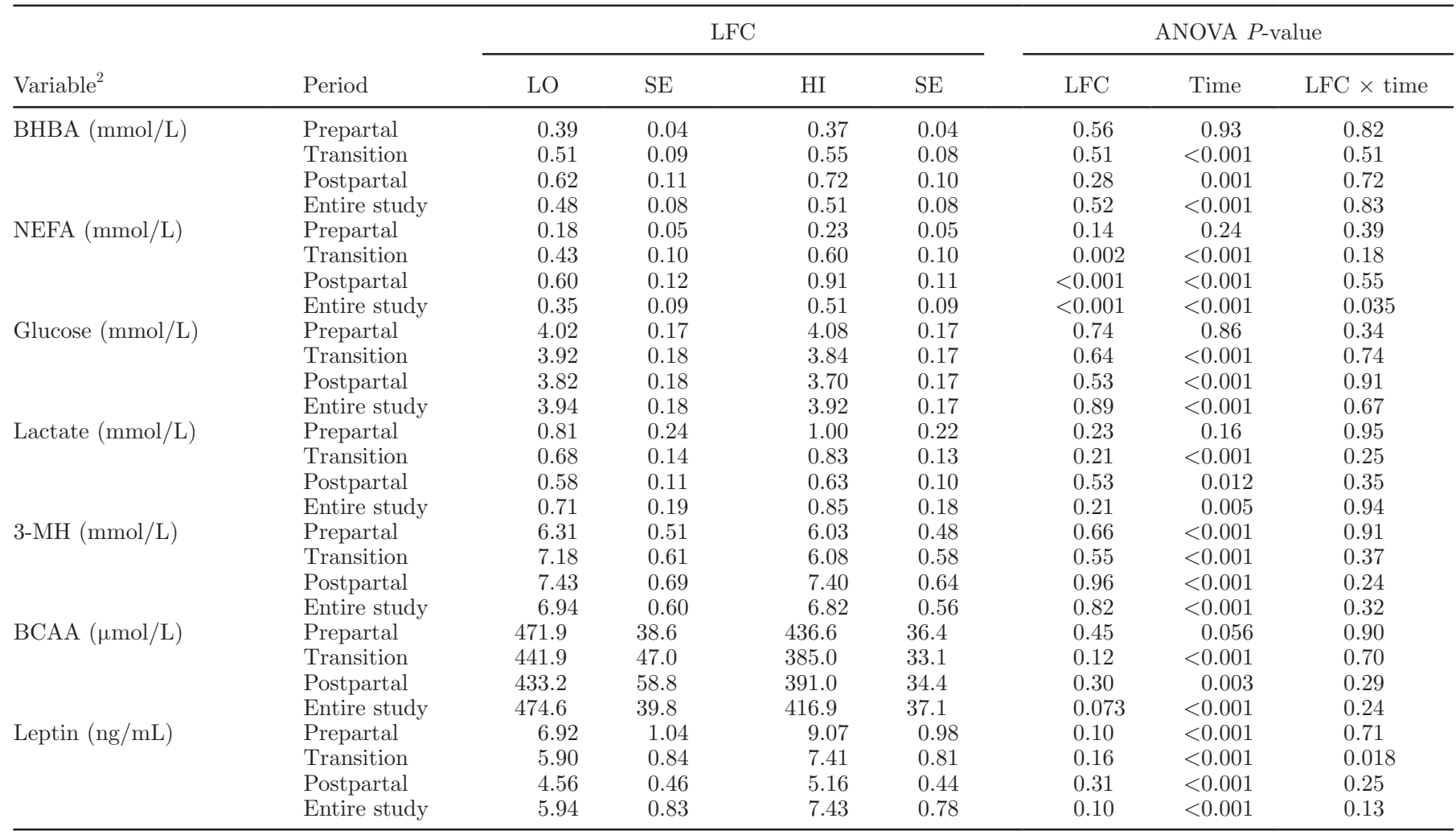

${ }^{1}$ Data are presented as LSM with their SE.

${ }^{2} 3$-MH $=3$-methyl histidine; BCAA $=$ branched-chain amino acids. 
Table 4. Muscle fat, protein, glycogen, and glucose content in percentage of wet weight of cows with a low (LO) or high (HI) liver fat content (LFC) postpartum ${ }^{1}$

\begin{tabular}{|c|c|c|c|c|c|c|}
\hline \multirow[b]{2}{*}{ Variable } & \multirow[b]{2}{*}{ d } & \multicolumn{4}{|c|}{ Content ( $\%$ of wet weight) } & \multirow{2}{*}{$\frac{\text { ANOVA } P \text {-value }}{\text { LFC }}$} \\
\hline & & $\mathrm{LO}$ & $\mathrm{SE}$ & HI & $\mathrm{SE}$ & \\
\hline \multirow[t]{3}{*}{ Muscle fat } & -17 & 0.61 & 0.32 & 1.63 & 0.32 & \multirow[t]{3}{*}{0.042} \\
\hline & 3 & 0.65 & 0.40 & 1.02 & 0.32 & \\
\hline & 30 & 0.91 & 0.32 & 1.42 & 0.31 & \\
\hline \multirow[t]{3}{*}{ Muscle protein } & -17 & 19.22 & 0.27 & 19.35 & 0.27 & \multirow[t]{3}{*}{0.51} \\
\hline & 3 & 20.37 & 0.34 & 20.22 & 0.27 & \\
\hline & 30 & 19.18 & 0.27 & 18.74 & 0.25 & \\
\hline \multirow[t]{3}{*}{ Muscle glycogen } & -17 & 0.18 & 0.07 & 0.11 & 0.07 & \multirow[t]{3}{*}{0.46} \\
\hline & 3 & 0 & 0 & 0 & 0 & \\
\hline & 30 & 0 & 0 & 0 & 0 & \\
\hline \multirow[t]{3}{*}{ Muscle glucose } & -17 & 0.51 & 0.51 & 0.59 & 0.03 & \multirow[t]{3}{*}{0.13} \\
\hline & 3 & 0 & 0 & 0 & 0 & \\
\hline & 30 & 0 & 0 & 0 & 0 & \\
\hline
\end{tabular}

${ }^{1}$ Data are presented as LSM with their SE.

(Hammon et al., 2009). Accordingly, plasma NEFA concentrations peaked during early lactation and were higher in HI than in LO cows. During this time, released NEFA are partly used for the synthesis of milk fat, which was also higher in HI than in LO cows. The decrease in milk fat content parallels, therefore, the decrease in plasma NEFA concentrations (van Knegsel et al., 2007). The skeletal muscle may also contribute to the degradation of FA because intensive walking activity in postpartum dairy cows was negatively correlated with plasma NEFA concentrations (Adewuyi et al., 2006). Plasma leptin, a marker for triglyceride mobilization from adipose tissue, decreased after parturition in both groups and tended to be higher in HI compared with LO cows. These differences parallel the differences in BFT decrease and are in accordance with those of Hammon et al. (2009). Nevertheless, leptin's role in stimulating FAO in skeletal muscle (Fuentes et al., 2010) around parturition seems to be marginal, because leptin concentrations decreased from late pregnancy to parturition and were not different between groups during transition $(P>0.15$; Table 3$)$, but this assumption needs to be confirmed in future studies (e.g., on leptin receptor signaling).

Long and very long-chain FA are transported into the mitochondria via CPT where they undergo $\beta$-oxidation. In muscle, the predominant form is CPT1B, which has a different enzyme kinetic [higher values of the Michaelis constant $\left(K_{\mathrm{m}}\right)$ for palmitoyl-CoA and carnitine but lower $K_{\mathrm{m}}$ values for malonyl-CoA] compared with CPT1A (Price et al., 2003); $C P T 1 A$ and $C P T 1 B$ were found upregulated in early lactation, whereas $C P T 1 B$ was highest on $\mathrm{d} 3$ and CPT1A was highest on $\mathrm{d} 30$, suggesting an increased transport of FA from the cytosol into mitochondria in early lactation. The reduced $C P T 1 B$ abundance from d 3 to 30 might be due to higher malonyl-CoA concentration, the latter the inhib- itor for CPT1 and precursor for fat synthesis. Interestingly, muscle fat increased from d 3 to 30 . The higher entrance of FA into the mitochondria was followed by an upregulation of the $\beta$-oxidative genes $A C A D V L$ and $A C A A 2$ but not $H A D H$ on d 3. Accordingly, strong positive correlations were observed between changes in $A C A D V L$ or $A C A A 2$, respectively, and $C P T 1 B$. However, it remains speculative if the increase in $C P T 1 A$ and $C P T 1 B$ mRNA abundances coincide with the postpartal NEFA peak because only 2 muscle samples were taken in early lactation.

Rising NEFA concentrations generally lead to increased mRNA abundance of the PPAR family, which are all key regulators of FAO or lipogenesis (Muoio and Koves, 2007; Brennan et al., 2009). We found increased abundance of the FA sensor PPARG after parturition which was higher in HI compared with LO cows, assuming a higher lipogenesis (Evans et al., 2004) in HI cows, although not reflected by the higher muscle fat content at $\mathrm{d} 30$. In contrast, mRNA PPARA abundance decreased after parturition; however, PPARA is not the dominant form in muscle.

The most abundant PPAR form in skeletal muscle is PPARD (Brennan et al., 2009), which may interact with PPARGC1A and thereby promotes complete FAO (Consitt et al., 2010). Although PPARD was highest in abundance on $\mathrm{d} 3$, the abundance of PPARGC1A decreased after parturition, suggesting that either the $P P A R D$ promoting effect on FAO is not dependent on the interaction with $P P A R G C 1 A$ in early lactation, or that muscle FAO is incomplete during this time. Upregulation of $P P A R D$ on d 3 may promote the first steps of $\beta$-oxidation, whereas decreasing PPARD abundance by d 30 may rather impede complete FAO. Based on the group $\times$ time interaction for PPARD and $C P T 1 B$ and the higher PPARD and $C P T 1 B$ abundances in $\mathrm{LO}$ cows after parturition, we conclude that complete muscle 
PPARA

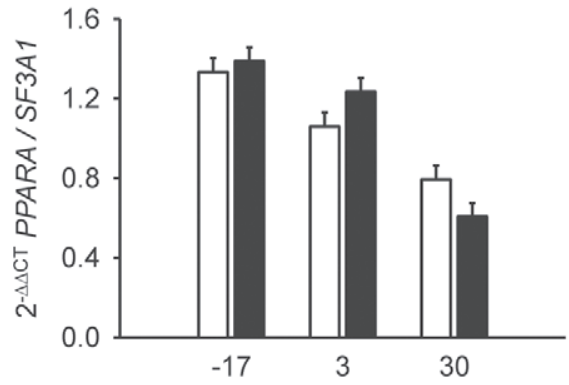

PPARGC1A

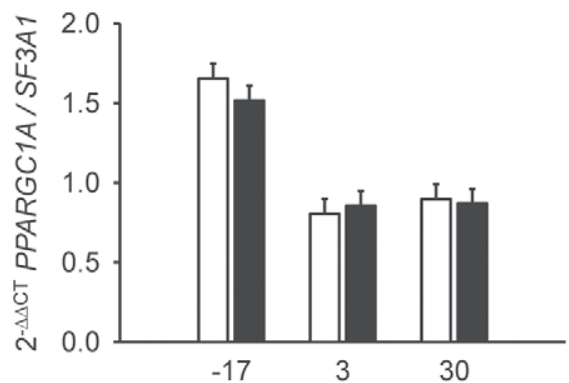

$H A D H$
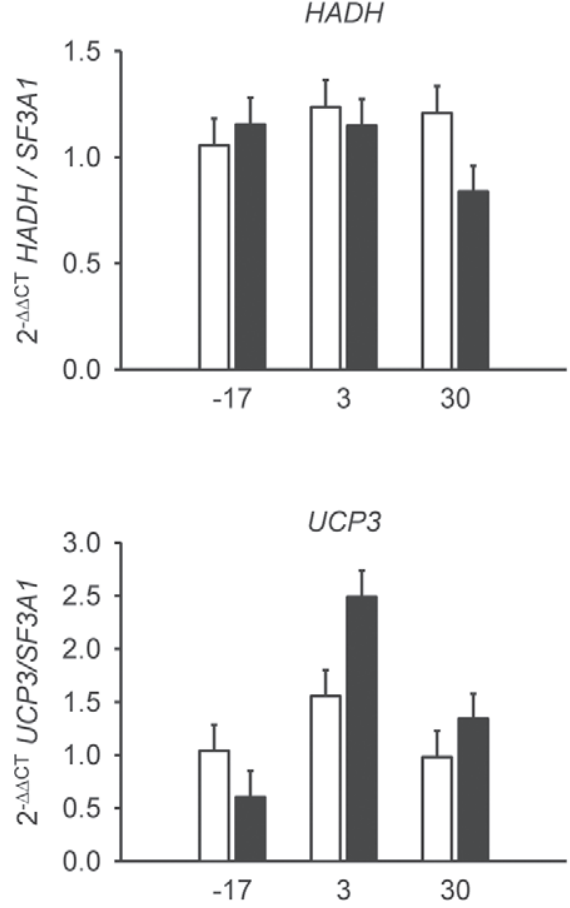

Day relative to parturition
PPARG

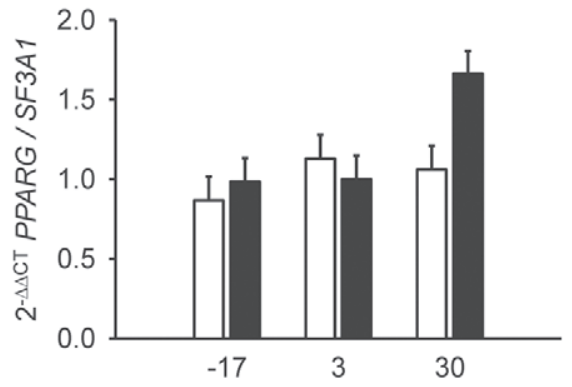

CPT1A

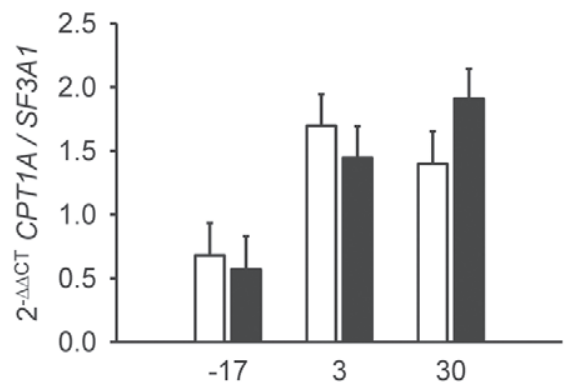

ACADVL

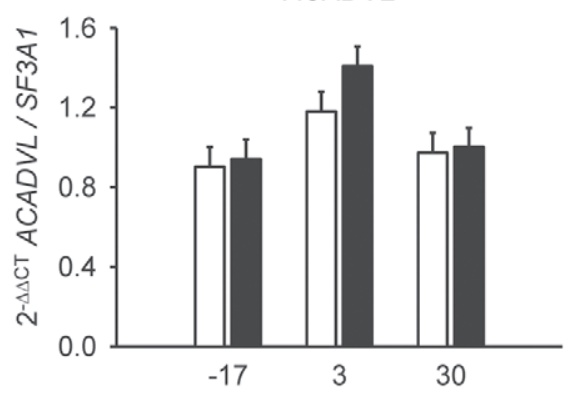

PAMPK

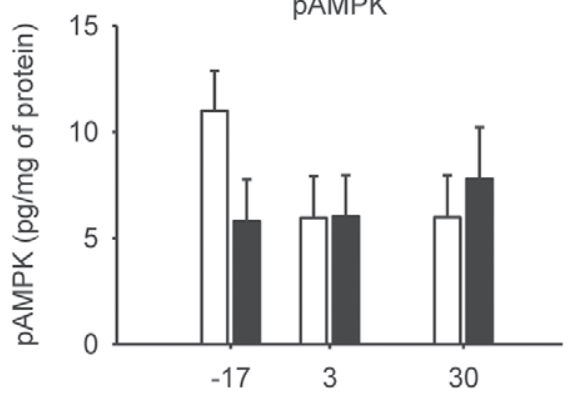

Day relative to parturition
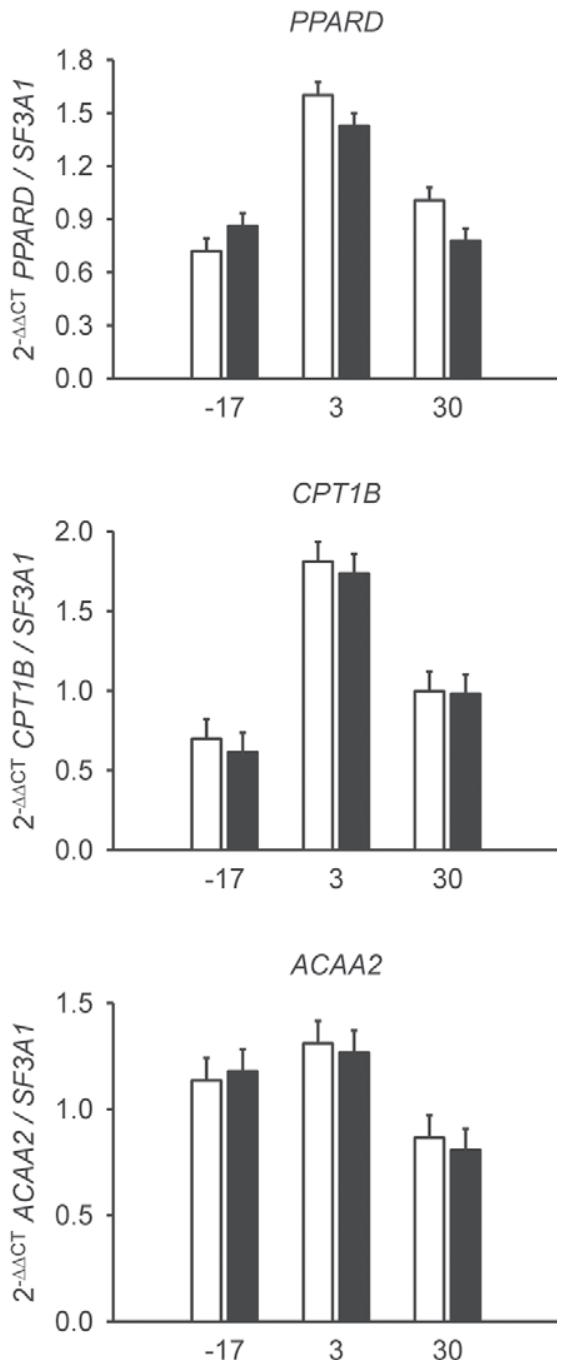

Day relative to parturition

Figure 2. Messenger RNA abundance of the peroxisome proliferator-activated receptors $P P A R A, P P A R G, P P A R D$, the $P P A R G$ coactivator $1 \alpha(P P A R G C 1 A)$, carnitine palmitoyltransferase $1 \alpha(C P T 1 A)$ and $1 \beta(C P T 1 B), 3$-hydroxyacyl-CoA dehydrogenase $(H A D H)$, very long-chain acyl-CoA dehydrogenase $(A C A D V L)$, 3-ketoacyl-CoA thiolase (ACAA2), and uncoupling protein 3 (UCP3), as well as the concentration of phosphorylated AMP-activated protein kinase (pAMPK) in skeletal muscle of cows with a different extent of body tissue mobilization [lowest-bodyfat-mobilizing (LO) cows: white bars; highest-body-fat-mobilizing (HI) cows: black bars]. Messenger RNA abundance differed between HI and LO cows for PPARG $(P<0.05)$ and for all transcripts in time (for UCP3, PPARA, PPARD, PPARGC1A, CPT1A and CPT1B, and ACAA2: $P<0.001$; for ACADVL: $P<0.01$; for PPARG: $P<0.05)$ except for $H A D H(P=0.7)$. A group $\times$ time interaction was found for $U C P 3$ and $P P A R D(P<0.05) ; P P A R A$ and $P P A R G$ as well as $C P T 1 B$ tended to interact between group and time $(P=0.08, P=0.06$, and $P=0.05$, respectively). Muscle pAMPK was unaltered over time $(P=0.3)$ and between groups $(P=0.6)$. CT $=$ cycle threshold. 
A $\quad d-17$ to $d 3$

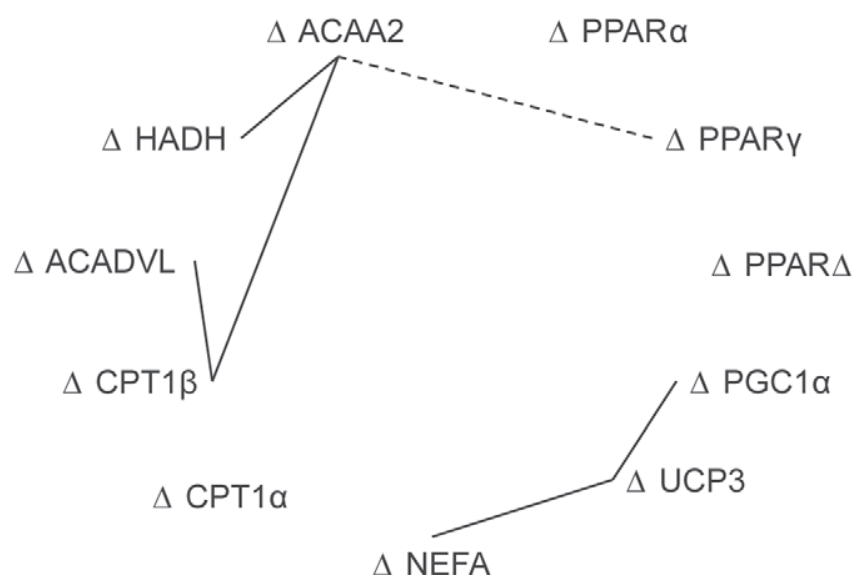

B $\quad$ d 3 to $d 30$

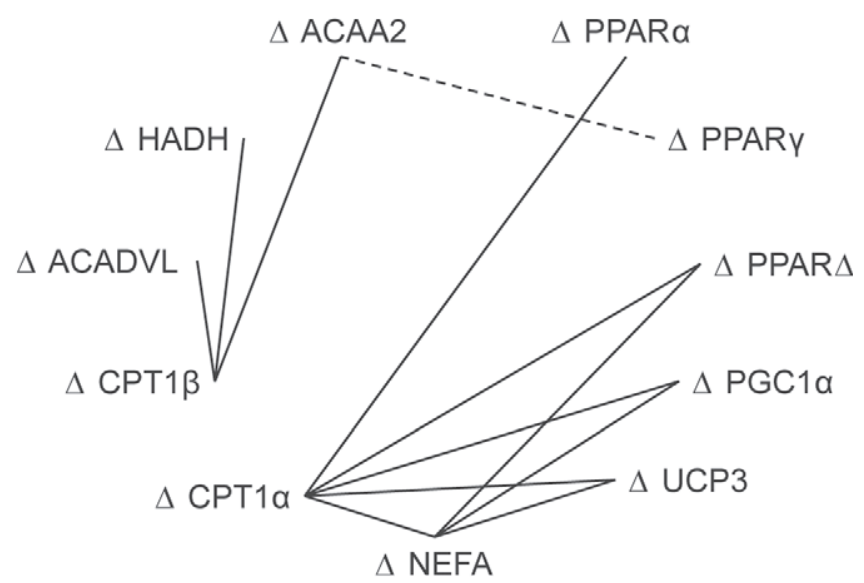

Figure 3. Correlations between differences $(\Delta)$ in mRNA abundance or plasma NEFA concentrations occurring from d -17 to 3 (A) or from d 3 to 30 (B). Solid lines indicate direct correlations, whereas dashed lines indicate inverse correlations, with $P \leq 0.05$. ACAA2 $=3$-ketoacyl$\mathrm{CoA}$ thiolase; PPAR = peroxisome proliferator-activated receptor; PGC1 $\alpha=$ PPAR $\gamma$ coactivator $1 \alpha$; UCP3 = uncoupling protein 3 ; CPT1 $=$ carnitine palmitoyltransferase 1; ACADVL = very long-chain acyl-CoA dehydrogenase; HADH $=3$-hydroxyacyl-CoA dehydrogenase.

FAO was more pronounced in LO than in HI cows during early lactation. Incomplete or limited FAO results in the formation of acylcarnitines or 3-hydroxy FA, thereby contributing to insulin resistance in peripheral tissues (Koves et al., 2008), which in turn facilitates net mobilization of amino acids from these tissues in the early lactation period (Bell et al., 2000).

Rising NEFA concentrations and the interaction between PPARD and PPARGC1A may trigger the activation of UCP3 (Musa et al., 2012) from d -17 before to d 3 after parturition. Accordingly, we found changes of UCP3 mRNA abundance positively correlated with changes of NEFA concentrations throughout the periparturient period, as well as with changes of PPARG$C 1 A$ mRNA abundance before parturition. Considering that $U C P 3$ is responsive to elevated fasting-induced NEFA concentrations in cattle (Brennan et al., 2009), the highest abundance of $U C P 3$ together with PPARD and $C P T 1 B$ on d 3 supports the idea that muscle metabolism switches from glycolytic to a more oxidative type by preferring FA as fuel (de Lange et al., 2007). This switch is mainly regulated by PPARD (Moreno et al., 2010), which is particularly present in oxidative muscle fibers (de Lange et al., 2007). Moreover, due to its primary role in transporting non-oxidizable FA out of the mitochondria, upregulation of UCP 3 by d 3 may prevent myocytes from lipotoxicity during increased $\beta$-oxidation (Schrauwen and Hesselink, 2004). Taken together, upregulation of $C P T 1 B, P P A R D, U C P 3$, and $\beta$-oxidative enzymes from $\mathrm{d}-17$ before to $\mathrm{d} 3$ after parturition indicate induced muscle FAO. This conclusion is supported by the earlier described upregulation of muscle retinal dehydrogenase producing retinoic acid as a ligand for PPAR signaling in the second week of lactation (Kuhla et al. 2011). Therefore, increased muscle FAO around parturition could contribute in reducing the metabolic load of FA on the liver.

We further found a group $\times$ time interaction for UCP3. The higher abundance of UCP3 in HI than in LO cows in early lactation indicates a higher export of non-oxidizable FA from the mitochondria. Those non-oxidizable FA may be lipid peroxides that are produced in the reaction with reactive oxygen species generated during UCP3 mediated uncoupling (Hoeks et al., 2012). Considering the lower PPARD but higher $U C P 3$ mRNA abundance in HI cows in early lactation, it seems that HI cows have the higher incomplete but lower complete muscle FAO. Similarly, myocytes from humans with a high fat load had the lower complete and the higher incomplete FAO compared with lean counterparts (Consitt et al., 2010).

From d 3 to 30 of early lactation, however, UCP3 mRNA abundance decreased again. Similarly, UCP3 mRNA abundance is reduced in the muscle of early lactating compared with nonpregnant rats (Xiao et al., 2004). This decrease is accompanied by a reduction in PPARA, PPARD, and CPT1B mRNA abundance by $\mathrm{d}$ 30 , indicating decreasing muscle FAO, whereas plasma NEFA concentrations remain elevated. A limited increasing or decreasing muscle FAO by d 30 of lactation may save and direct FA for milk production (de Lange et al., 2007), but also allows the fat content of muscle tissue to increase again from d 3 to 30 . This repletion of muscle fat is either due to reesterification of longchain FA or de novo synthesis from acetate, which is sufficiently supplied by the increase in feed intake in 
early lactation. Consequently, the reduced long-chain FA and also glucose utilization by the skeletal muscle in early lactation (Kuhla et al., 2011) could be compensated by increased acetate utilization as the preferred fuel source. Intragastrically administrated acetate was shown to induce the expression of UCP and PPAR and CPT1 in the liver of mice (Kondo et al., 2009), but this effect has not been observed for the muscle in the present study. How UCP3, CPT, and PPAR are regulated in response to an increased acetate supply in the bovine muscle remains to be determined.

Another major player promoting fat oxidation is AMPK. Phosphorylated in times of energy deficiency, phosphorylated AMPK signals the inhibition of acetylCoA carboxylase, thereby suppressing malonyl-CoA synthesis and thus enabling FA transport via CPT1 in skeletal muscle (Kahn et al., 2005). However, we found no differences in AMPK phosphorylation between groups or during the periparturient period, suggesting that during this time, the muscle is sufficiently supplied with ATP, either via glycolysis, FAO, or by acetate oxidation. The switch in fuel selection of the skeletal muscle together with the degradation and repletion of muscle energy reserves during the periparturient period indicate the great metabolic flexibility of the muscle. This integrates the muscle into homeorhesis, which has been defined as the orchestrated and coordinated control of body tissue metabolism aligned to partition nutrients and energy to the dominant process of milk production (Bauman and Currie, 1980).

\section{CONCLUSIONS}

Taken together, we found the highest mRNA abundance of genes involved in skeletal muscle FA transport and oxidation $3 \mathrm{~d}$ after parturition. During this time, plasma NEFA concentrations still increased, reaching a maximum later in early lactation. Although mRNA abundance does not necessarily reflect protein abundance or enzyme activity, our results led us assume that transport of FA into muscle mitochondria and subsequent $\mathrm{FAO}$ respond to fat mobilization around parturition and thus help to protect the liver from excess fat load. The higher extent of fat mobilization, however, is associated with increased incomplete and reduced complete muscle FAO. From d 3 to 30 of lactation, mRNA abundance of genes involved in muscle FAO decreases, supporting repletion of muscle fat and sparing FA for milk fat synthesis.

\section{ACKNOWLEDGMENTS}

We thank M. Althaus, S. Foß, K. Karpati, U. Lüdtke, and the staff at the FBN cattle facility and at the
Tiertechnikum (Dummerstorf, Germany) for help with biochemical analyses and animal care, and B. Mielenz (University of Bonn, Bonn, Germany) for measurement of leptin. We further acknowledge the help of the Cattle Breeding Organization Mecklenburg-West Pomerania (RMV, Germany) and the Griepentrog farm (Steinhagen, Germany) for the assortment of cows. This study was supported by Deutsche Forschungsgemeinschaft (DFG; Bonn, Germany; KU 1956/4-1).

\section{REFERENCES}

Adewuyi, A. A., J. B. Roelofs, E. Gruys, M. J. M. Toussaint, and F. J. C. M. van Eerdenburg. 2006. Relationship of plasma nonesterified fatty acids and walking activity in postpartum dairy cows. J. Dairy Sci. 89:2977-2979.

Bauman, D. E., and W. B. Currie. 1980. Partitioning of nutrients during pregnancy and lactation: A review of mechanisms involving homeostasis and homeorhesis. J. Dairy Sci. 63:1514-1529.

Bell, A. W., W. S. Burhans, and T. R. Overton. 2000. Protein nutrition in late pregnancy, maternal protein reserves and lactation performance in dairy cows. Proc. Nutr. Soc. 59:119-126.

Blum, J. W., T. Reding, F. Jans, M. Wanner, M. Zemp, and K. Bachmann. 1985. Variations of 3-methylhistidine in blood of dairy cows. J. Dairy Sci. 68:2580-2587.

Bobe, G., J. W. Young, and D. C. Beitz. 2004. Invited review: Pathology, etiology, prevention, and treatment of fatty liver in dairy cows. J. Dairy Sci. 87:3105-3124.

Brennan, K. M., J. J. Michal, J. J. Ramsey, and K. A. Johnson. 2009. Body weight loss in beef cows: I. The effect of increased beta-oxidation on messenger ribonucleic acid levels of uncoupling proteins two and three and peroxisome proliferator-activated receptor in skeletal muscle. J. Anim. Sci. 87:2860-2866.

Consitt, L. A., J. A. Bell, T. R. Koves, D. M. Muoio, M. W. Hulver, K. R. Haynie, G. L. Dohm, and J. A. Houmard. 2010. Peroxisome proliferator-activated receptor- $\gamma$ coactivator- $1 \alpha$ overexpression increases lipid oxidation in myocytes from extremely obese individuals. Diabetes 59:1407-1415.

de Lange, P., M. Moreno, E. Silvestri, A. Lombardi, F. Goglia, and A. Lanni. 2007. Fuel economy in food-deprived skeletal muscle: Signaling pathways and regulatory mechanisms. FASEB J. 21:34313441.

Doepel, L., H. Lapierre, and J. J. Kennelly. 2002. Peripartum performance and metabolism of dairy cows in response to prepartum energy and protein intake. J. Dairy Sci. 85:2315-2334.

Drackley, J. K., T. R. Overton, and G. N. Douglas. 2001. Adaptations of glucose and long-chain fatty acid metabolism in liver of dairy cows during the periparturient period. J. Dairy Sci. 84(E. Suppl.):E100-E112.

Evans, R. M., G. D. Barish, and Y.-X. Wang. 2004. PPARs and the complex journey to obesity. Nat. Med. 10:355-361.

Fuentes, T., I. Ara, A. Guadalupe-Grau, S. Larsen, B. Stallknecht, H. Olmedillas, A. Santana, J. W. Helge, J. A. L. Calbet, and B. Guerra. 2010. Leptin receptor $170 \mathrm{kDa}(\mathrm{OB}-\mathrm{R} 170)$ protein expression is reduced in obese human skeletal muscle: A potential mechanism of leptin resistance. Exp. Physiol. 95:160-171.

GfE (German Society of Nutrition Physiology). 2001. Recommended energy and nutrient supply for dairy cows and growing cattle. DLG-Verlag, Frankfurt am Main, Germany.

Grummer, R. R. 1993. Etiology of lipid-related metabolic disorders in periparturient dairy cows. J. Dairy Sci. 76:3882-3896.

Hammon, H. M., G. Stürmer, F. Schneider, A. Tuchscherer, H. Blum, T. Engelhard, A. Genzel, R. Staufenbiel, and W. Kanitz. 2009. Performance and metabolic and endocrine changes with emphasis on glucose metabolism in high-yielding dairy cows with high and low fat content in liver after calving. J. Dairy Sci. 92:1554-1566.

Hoeks, J., Z. Arany, E. Phielix, E. Moonen-Kornips, M. K. C. Hesselink, and P. Schrauwen. 2012. Enhanced lipid- but not carbo- 
hydrate-supported mitochondrial respiration in skeletal muscle of PGC-1 $\alpha$ overexpressing mice. J. Cell. Physiol. 227:1026-1033.

Janovick, N. A., and J. K. Drackley. 2010. Prepartum dietary management of energy intake affects postpartum intake and lactation performance by primiparous and multiparous Holstein cows. J. Dairy Sci. 93:3086-3102.

Kahn, B. B., T. Alquier, D. Carling, and D. G. Hardie. 2005. AMPactivated protein kinase: Ancient energy gauge provides clues to modern understanding of metabolism. Cell Metab. 1:15-25.

Kessel, S., M. Stroehl, H. H. D. Meyer, S. Hiss, H. Sauerwein, F. J. Schwarz, and R. M. Bruckmaier. 2008. Individual variability in physiological adaptation to metabolic stress during early lactation in dairy cows kept under equal conditions. J. Anim. Sci. $86: 2903-2912$

Kondo, T., M. Kishi, T. Fushimi, and T. Kaga. 2009. Acetic acid upregulates the expression of genes for fatty acid oxidation enzymes in liver to suppress body fat accumulation. J. Agric. Food Chem. 57:5982-5986.

Koves, T. R., J. R. Ussher, R. C. Noland, D. Slentz, M. Mosedale, O. Ilkayeva, J. Bain, R. Stevens, J. R. B. Dyck, C. B. Newgard, G. D. Lopaschuk, and D. M. Muoio. 2008. Mitochondrial overload and incomplete fatty acid oxidation contribute to skeletal muscle insulin resistance. Cell Metab. 7:45-56.

Kuhla, B., G. Nürnberg, D. Albrecht, S. Görs, H. M. Hammon, and C. C. Metges. 2011. Involvement of skeletal muscle protein, glycogen, and fat metabolism in the adaptation on early lactation of dairy cows. J. Proteome Res. 10:4252-4262.

Kuhla, S., M. Klein, U. Renne, W. Jentsch, P. E. Rudolph, and W. B. Souffrant. 2004. Carbon and nitrogen content based estimation of the fat content of animal carcasses in various species. Arch. Anim. Nutr. 58:37-46.

Livak, K. J., and T. D. Schmittgen. 2001. Analysis of relative gene expression data using real-time quantitative PCR and the $2^{-\triangle \Delta \mathrm{CT}}$ method. Methods 25:402-408.

Moreno, M., A. Lombardi, E. Silvestri, R. Senese, F. Cioffi, F. Goglia, A. Lanni, and P. de Lange. 2010. PPARs: Nuclear receptors controlled by, and controlling, nutrient handling through nuclear and cytosolic signaling. PPAR Res. 2010: http://dx.doi. org $/ 10.1155 / 2010 / 435689$.

Muoio, D. M., and T. R. Koves. 2007. Skeletal muscle adaptation to fatty acid depends on coordinated actions of the PPARs and

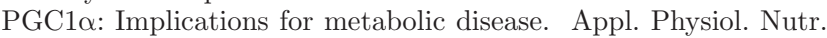
Metab. 32:874-883.

Musa, C. V., A. Mancini, A. Alfieri, G. Labruna, G. Valerio, A. Franzese, F. Pasanisi, M. R. Licenziati, L. Sacchetti, and P. Buono. 2012. Four novel UCP3 gene variants associated with childhood obesity: Effect on fatty acid oxidation and on prevention of triglyceride storage. Int. J. Obes. (Lond.) 36:207-217.

Nicastro, H., C. R. da Luz, D. F. Seixas Chaves, L. R. Grassmann Bechara, V. A. Voltarelli, M. M. Rogero, and A. H. Lancha Jr. 2012. Does branched-chain amino acids supplementation modulate skeletal muscle remodeling through inflammation modulation? Possible mechanisms of action. J. Nutr. Metab. http://dx.doi. org $/ 10.1155 / 2012 / 136937$.

Pérez, R., I. Tupac-Yupanqui, and S. Dunner. 2008. Evaluation of suitable reference genes for gene expression studies in bovine muscular tissue. BMC Mol. Biol. http://dx.doi.org/10.1186/1471-2199-979

Price, N. T., V. N. Jackson, F. R. van der Leij, J. M. Cameron, M. T Travers, B. Bartelds, N. C. Huijkman, and V. A. Zammit. 2003 Cloning and expression of the liver and muscle isoforms of ovine carnitine palmitoyltransferase 1: Residues within the N-terminus of the muscle isoform influence the kinetic properties of the enzyme. Biochem. J. 372:871-879.

Reist, M., D. Erdin, D. von Euw, K. Tschuemperlin, H. Leuenberger, Y. Chilliard, H. M. Hammon, C. Morel, C. Philipona, Y. Zbinden, N. Kuenzi, and J. W. Blum. 2002. Estimation of energy balance at the individual and herd level using blood and milk traits in highyielding dairy cows. J. Dairy Sci. 85:3314-3327.

Ringseis, R., K. Heller, H. Kluge, and K. Eder. 2011. mRNA expression of genes involved in fatty acid utilization in skeletal muscle and white adipose tissues of sows during lactation. Comp. Biochem. Physiol. A Mol. Integr. Physiol. 158:450-454.

SAS Institute. 2009. SAS/STAT ${ }^{\circledR} 9.2$ User's Guide. 2nd ed. SAS Institute Inc., Cary, NC

Sauerwein, H., U. Heintges, M. Hennies, T. Selhorst, and A. Daxenberger. 2004. Growth hormone induced alterations of leptin serum concentrations in dairy cows as measured by a novel enzyme immunoassay. Livest. Prod. Sci. 87:189-195.

Schäff, C., S. Börner, S. Hacke, U. Kautzsch, H. M. Hammon, M. Röntgen, and B. Kuhla. 2012. Increased anaplerosis, TCA cycling and oxidative phosphorylation in the liver of dairy cows with intensive body fat mobilization during early lactation. J. Proteome Res. 11:5503-5514.

Schrauwen, P., and M. K. Hesselink. 2004. The role of uncoupling protein 3 in fatty acid metabolism: Protection against lipotoxicity? Proc. Nutr. Soc. 63:287-292.

van der Drift, S. G. A., M. Houweling, J. T. Schonewille, A. G. M. Tielens, and R. Jorritsma. 2012. Protein and fat mobilization and associations with serum $\beta$-hydroxybutyrate concentrations in dairy cows. J. Dairy Sci. 95:4911-4920.

van Knegsel, A. T., H. van den Brand, E. A. Graat, J. Dijkstra, R. Jorritsma, E. Decuypere, S. Tamminga, and B. Kemp. 2007. Dietary energy source in dairy cows in early lactation: Metabolites and metabolic hormones. J. Dairy Sci. 90:1477-1485.

Weber, C., C. Hametner, A. Tuchscherer, B. Losand, E. Kanitz, W. Otten, S. P. Singh, R. M. Bruckmaier, F. Becker, W. Kanitz, and H. M. Hammon. 2013. Variation in fat mobilization during early lactation differently affects feed intake, body condition, and lipid and glucose metabolism in high-yielding dairy cows. J. Dairy Sci. 96:165-180.

Xiao, X. Q., K. L. Grove, and M. S. Smith. 2004. Metabolic adaptations in skeletal muscle during lactation: Complementary deoxyribonucleic acid microarray and real-time polymerase chain reaction analysis of gene expression. Endocrinology 145:5344-5354.

Zammitt, V. A. 1984. Mechanisms of regulation on the partition of fatty acids between oxidation and esterification in the liver. Prog. Lipid Res. 23:39-67.

Zanchi, N. E., H. Nicastro, and A. H. Lancha Jr. 2008. Potential antiproteolytic effects of L-leucine: Observations of in vitro and in vivo studies. Nutr. Metab. (Lond.) 5:20. 